\title{
Importing Gendered Legal Reasoning from England: Wife Murders in Early Colonial India, 18051857
}

\section{Grey, DJR}

http://hdl.handle.net/10026.1/8328

10.1080/14780038.2017.1329123

Cultural and Social History

All content in PEARL is protected by copyright law. Author manuscripts are made available in accordance with publisher policies. Please cite only the published version using the details provided on the item record or document. In the absence of an open licence (e.g. Creative Commons), permissions for further reuse of content should be sought from the publisher or author. 
This is the author's accepted manuscript. The final published version of this work (the version of record) is published by Taylor \& Francis Online in Cultural and Social History available at: http://www.tandfonline.com/loi/rfcs20. This work is made available online in accordance with the publisher's policies. Please refer to any applicable terms of use of the publisher.

\section{IMPORTING GENDERED LEGAL REASONING FROM ENGLAND: WIFE MURDERS IN EARLY COLONIAL INDIA, 1805-1857}

\section{Daniel J.R. Grey}

\section{INTRODUCTION}

In July 1825, the Supreme Criminal Court for Bengal, known as the Nizamat Adalat, reviewed the case of Chait Ram, a man who had been charged at the Bareilly sessions with the murder of his wife, Mussumaut Dhunkeeah. ${ }^{1}$ Ram freely admitted killing her and even identified the weapon he had used, but claimed the murder was the result of his wife's adultery with a neighbour. Since the killing of a wife caught in the act of adultery was not a crime under Islamic law, and all Indians charged with crimes in the first half of the nineteenth century - regardless of their own religion - were dealt with by British judges in relation to this system of jurisprudence, the qazis (Islamic law officers) of both the sessions court and the Nizamat Adalat recommended he be released from custody at once. ${ }^{2}$ While one of the three officiating British judges argued that Ram had not sufficiently proven that his wife had indeed been conducting an affair, and suggested that a sentence of life imprisonment would be appropriate given the circumstances, his two colleagues disagreed and upheld the qazis ruling. Ram was freed immediately 'without further punishment'.

At one level, the case of Chait Ram and the decision of the British officials to follow the recommendation of the Muslim legal scholars who reviewed it can perhaps be seen as 
part of the wider policy of early colonial rulers to attempt to maintain the facade of benevolence by not interfering overtly with established Indian legal practice. Yet the Nizamat Adalat played a central role in the rise of the new 'Anglo-Muhammadan' criminal law that developed between the late-eighteenth and mid-nineteenth century. ${ }^{4}$ British judges had few qualms dismissing reports by Islamic law officers when they fundamentally disagreed with the judgment given. Moreover, an approach which focuses exclusively on what such verdicts meant in terms of the perception of violence in India ignores the fact that remarkably similar cases of wife-killing - and remarkably similar outcomes - were by no means unusual back in Britain. Indeed, it was well established by precedents in both English and Scots law dating back to at least the sixteenth century that if a man caught his wife in the act of adultery and killed one or both of them on the spot, this should always be treated as manslaughter rather than the capital offence of murder. ${ }^{5}$ The informal criminal defence in India of 'injured masculine honour' was dramatically narrowed from the turn of the nineteenth century onwards. ${ }^{6}$ Yet in practice this remained a popular - and extremely effective - appeal by men to the judiciary throughout the colonial period. ${ }^{7}$ As Padma Anagol has demonstrated for Western India, this willingness to accept pleas of provocation by men as mitigating domestic murders did not apply to those cases of Indian wives who killed their husbands, since these women were frequently portrayed as cold-blooded schemers. ${ }^{8}$ The English courts also substantially tightened their understanding of what counted as 'provocation' during these decades, yet it remained the case that a certain level of violence towards wives could still be dismissed as constituting legitimate correction.

As Catherine Hall and others have noted, events in Britain and its Empire never occurred in isolation from each other, but there was a complicated and ongoing reciprocal relationship between colony and metropole throughout and beyond the nineteenth century. ${ }^{9}$ 
Moreover, these links and transfers were not inevitably confined to a linear back and forth of exchanges in culture, law and politics centred on Britain itself, but such metaphorical and material border crossings could and did occur between different colonies as well, with or without also returning to the United Kingdom. ${ }^{10}$ As Kirsten McKenzie has observed, 'What was gossip in Cape Town could soon become gossip in Sydney, Calcutta or London'. ${ }^{11}$ In recent years, historians have become increasingly interested in the ways that law did - or, perhaps more surprisingly, sometimes did not - become a part of this process of crossing borders. ${ }^{12}$ Legal pluralism formed a major element of colonial policy and practice for all European powers, and Britain was no exception. ${ }^{13}$ Despite the inherently hierarchical nature of the British Empire and the privileged status within it of English common and statute law, perhaps most emphatically demonstrated by the fact that the Judicial Committee of the Privy Council formed the ultimate court of appeal for all British-held overseas territories from 1833 onwards, ${ }^{14}$ colonial legal systems never simply abolished pre-existing laws entirely or exported those from 'back home' without amendment. White settler societies in particular were often able to demand that their 'local' perspectives were taken into consideration when formulating legislation that had originally been proposed in London, insisting that the combination of whiteness and their personal knowledge of these regions necessitated that their input on whether such laws and their operation were 'right' should be taken seriously. ${ }^{15}$ Yet, not only was the idea of overarching 'British justice' frequently held up as a key element of the benign imperial project and as theoretically a resource available to indigenous colonial subjects, ${ }^{16}$ but so too was the idea of 'authenticity'. ${ }^{17}$ Especially during the late eighteenth and early nineteenth century, this idea was underscored by a supposed respectful adherence to indigenous laws and customs - at least wherever this was deemed possible within the boundaries of good governance and 'civilising influence'. ${ }^{18}$ David Washbrook has noted that 
although these competing and sometimes directly contradictory impulses were a key element in shaping colonial law, the paradoxes this generated were rarely if ever acknowledged. ${ }^{19}$

\section{METHODOLOGY AND CASE HISTORIES}

This article focuses on the reports of wife-murder cases that were reviewed by the Court of Nizamat Adalat between 1805, when the court first published its law reports, and the upheavals of 1857 that heralded dramatic changes to the judicial and administrative systems of colonial India. ${ }^{20}$ Based in Calcutta, the city that remained the seat of British power in India until 1911, the Nizamat Adalat was responsible for considering all criminal cases heard in Bengal Presidency - a span of territory covering not only a broad swathe of north-eastern India, but also including present-day Bangladesh - which either involved a capital sentence, a sentence of life imprisonment, or where a point of law had been questioned by the sessions judge trying a particular case. ${ }^{21}$ The Supreme Criminal Courts for Madras and Bombay (the Faujdari Adalats) followed similar procedures, although these did not publish their own reports on the cases they reviewed until the late $1840 \mathrm{~s} .{ }^{22}$ Prisoners themselves never appeared before the Nizamat Adalat. Instead, the court would be sent a collection of written reports about the trial, including the opinion of the sessions judge or magistrate on the proceedings, and the recommendation of the qazi attached to their court, who noted in turn what the verdict and sentence would be under Islamic law (sharia).$^{23}$ As noted above, in these cases Islamic law applied even to Hindu prisoners. These reports were then reviewed by the Islamic law officer of the Nizamat Adalat itself, whose own report was added (including whether this confirmed or disagreed with the fatwa issued by the other qazi), and the collated papers were then submitted to between one and three British judges for their consideration, with the possibility that the court might demand further investigations be carried out by the sessions court officials before handing down their judgement. ${ }^{24}$ As such, the reports never contain 
direct testimony by witnesses, the defendants, or court officials: at best these were recorded second hand. Reports could also vary tremendously in their level of detail when edited for publication: the reader can often be left with only tantalising fragments of information about the ways in which the court came to their eventual decision. Wherever possible, and particularly in cases where the possibility of insanity was raised, this collection of papers would also include reference to the findings of the civil surgeon who had been consulted by the sessions court to conduct a post-mortem on the victim or observe the prisoner in custody. ${ }^{25}$ Facilities and training for colonial medical jurisprudence were very limited at this time, the first such text, published in India in 1854 specifically lamented 'such is very rarely obtainable here; and the public officer must rely chiefly on himself ${ }^{26}$ Despite this, some judges at the Nizamat Adalat clearly made efforts to stay aware of the latest developments in the field. In one apparently unique instance, in a case from 1854 where the husband had attempted to disguise his wife's death as suicide by hanging, when considering the evidence the judges actually made specific reference to the relevant page number of the renowned American physician Thomas Beck's Elements of Medical Jurisprudence ${ }^{27}$ If theoretically the remit of the court was to deliver British interpretations of 'authentic' and 'fair' Islamic criminal law to Indian subjects, however, in practice, from 1807 onwards 'the criminal law applied in the Indian law courts had entirely lost its Islamic character except in name'. ${ }^{28}$ This was especially true with regards to homicide cases, since British officials found the existing Islamic legal system for dealing with unlawful killing, and the condoning of some types of homicide, to be problematic at best and reprehensible at worst. ${ }^{29}$ Stories of barbaric 'Oriental' crimes and the idea that these atrocities might be readily accepted by the population were common, such as the anecdote repeated by John Kaye in his 1853 history of the East India Company that an Indian man put on trial for cutting off his wife's nose in Madras during the 1760s as punishment for adultery had expressed bafflement that the British considered this a 
crime. ${ }^{30}$ Unsurprisingly, then, the colonial judges sitting in the Nizamat Adalat were, while working in an ostensibly separate legal system and bound by different rules, subtly but powerfully influenced by similar ideas and experiences to those of their peers in the English judiciary during this period. ${ }^{31}$ While further substantial reforms of the criminal law were mooted as early as the 1830s, in practice the existing judicial framework was only abolished after the uprising of 1857, and the subsequent imposition of the Indian Penal Code in 1860.

For a present-day reader who consults these reports, the high rate of lethal domestic violence that was dealt with by the Nizamat Adalat is particularly noticeable. Elizabeth Kolsky has pointed out that these killings of women by intimate partners accounted for more than a third of all the murder cases that were reviewed by the court in the first half of the nineteenth century. ${ }^{32}$ This article examines the treatment of 131 cases in which men were convicted of having murdered their wives had their sentence reviewed by the Nizamat Adalat between 1805 and 1857, located through combing through the law reports that were published by the court. While in 50 cases the death sentence passed by the sessions courts was confirmed (38 per cent of the total), it is worth noting that the next highest proportion of outcomes for this sample, 20 cases, (15.2 per cent of the total) was that the guilty husband was instead convicted following the review on the lesser charge of culpable homicide, and received the comparatively lenient sentence of imprisonment of five years or less - with or without hard labour (see Table 1.). Eighteen men (13.7 per cent of the total) were sentenced to transportation for life. ${ }^{33}$ Almost as high as this, however, seventeen men (12.9 per cent of the total) received a sentence of life imprisonment, either with or without hard labour. Depending on the view of the court as to how harshly a man should be punished, then, a man who killed his wife thus had roughly equivalent chances of having a death sentence 
commuted to life imprisonment, transportation for life, or the lesser sentence of up to five years in jail. Twelve men (9.1 per cent) were to be imprisoned for a term between 7 and 14 years. In just six instances during this period (4.5 per cent of the total) the court decreed after reviewing all the reports that the earlier conviction at the sessions court was unsafe, and ruled the accused man should be considered acquitted of the charge. ${ }^{34}$ In seven of these 131 cases (5.3 per cent of the total), one or more others - neighbours, brothers, cousins, and in one instance the guilty man's mother - were also accused by the sessions court of being either accessories to the murder, or attempting to conceal the killing from the authorities. Alleged accomplices (excluded from Table 1 below) were invariably handed down a lesser sentence by the Nizamat Adalat, since they were held to be less culpable than the guilty husband. The most severe judgment delivered to anyone convicted as an accomplice was the sentence of life imprisonment handed down in 1855 to Mussamaut Tara, the sole woman so accused, while her son had his death sentence confirmed for the murder of his wife. This severity was, however, little to do with the woman's unique status in the ranks of these accomplices as a female accessory to the murder of her adolescent daughter-in-law, and much more about the especially horrific circumstances of the crime: the victim had been subjected to sustained sexual torture before she died. ${ }^{35}$ 
TABLE 1. OUTCOME FOR HUSBANDS CONVICTED IN 131 WIFE-MURDER

CASES IN BENGAL THAT WERE REVIEWED BY THE NIZAMAT ADALAT, 1805-1857

\begin{tabular}{|c|c|c|c|c|c|c|c|c|}
\hline $\begin{array}{l}\text { DEATH } \\
\text { SENTENCE } \\
\text { CONFIRMED }\end{array}$ & $\begin{array}{l}\text { Imprisonment } \\
\text { for Life }\end{array}$ & Transport. & $\begin{array}{l}\text { Prison } \\
7-14 \\
\text { years }\end{array}$ & $\begin{array}{l}\text { Prison } \\
5 \\
\text { years } \\
\text { or } \\
\text { less }\end{array}$ & $\begin{array}{l}\text { Found } \\
\text { Insane }\end{array}$ & Released & Acquit. & $\begin{array}{l}\text { Died } \\
\text { awaiting } \\
\text { review } \\
\text { of trial }\end{array}$ \\
\hline 50 & 17 & 18 & 12 & 20 & 4 & 3 & 6 & 1 \\
\hline
\end{tabular}

It should be noted that this overall figure of 131 cases excludes those reviews by the court of the murder of concubines, charges of the culpable homicide of wives, and those instances in which men killed both their spouse and other relatives at the same time, since the former were perceived (rightly or wrongly) as holding a lesser status than wives, and the latter murders were invariably considered to be exceptional even by the standards of homicide cases and tended to incur more uniformly severe responses. ${ }^{36}$ Moreover, all cases of wife-killing reviewed by the court exclusively involved Indian married couples, rather than interracial married couples or European husbands and wives. There is also regrettably insufficient space here to consider the similarities and - more pointedly - the differences in the judicial treatment of indigenous defendants and of those European men living in India who were charged with the murder or assault of their wives at other courts. Cases such as that of Private Peter Hutchinson, a British soldier tried at Bombay in July 1846 for the murder of his wife after he had suspected her of adultery, could sometimes provoke heated debates about how such crimes should be dealt with. ${ }^{37}$ Yet despite the rhetoric of 'justice for all' so frequently employed by the British Empire, given the concern with preserving racial prestige 
and the ideal of white superiority, in several respects criminal trials of European defendants in India followed rather different (and invariably much more lenient) lines than those involving indigenous colonial subjects. ${ }^{38}$

\section{CULTURAL RELATIVISM AND DOMESTIC VIOLENCE IN THE NIZAMAT}

\section{ADALAT}

Before examining these cases in detail, it is first essential to set out the context for understanding how domestic violence (both lethal and not) was dealt with by the English legal system in this period, and the corresponding attitudes and precedents that British judges would have been aware of and influenced by while reviewing cases in Bengal. What constituted unacceptable behaviour within an English marriage, up to and including physical attacks, was a subject very much up for debate in the years covered by this article. Attitudes towards domestic violence were never monolithic. ${ }^{39}$ It was generally agreed that a husband might be allowed to 'give his wife moderate correction' ${ }^{40}$ That a husband was also allowed to physically confine his wife against her will was also accepted (however uncomfortably) until the case of $R$. v. Jackson in 1891 overturned this principle. ${ }^{41}$ Crucially, however, there was no firm consensus on what precisely this 'moderate correction' actually meant, and it was also affirmed in legal texts that 'this power of correction was confined within reasonable bounds, and the husband was prohibited from using any violence to his wife...' ${ }^{42}$ The 1790 ruling by Sir William Scott in the marital separation case of Evans v. Evans had simultaneously rejected setting out any formal definition what constituted of 'cruelty' while emphasising that emotional abuse did not fall under this heading, but only clear threats to physical well-being - although this might still be understood by the courts as a category that went beyond perpetrating physical violence alone. ${ }^{43}$ This view was reiterated by the Report of 
the Royal Commission on Divorce in 1853, who specifically commended Scott's interpretation. $^{44}$

That domestic violence might increasingly be perceived in Britain after 1800 as a specifically working-class issue, as it ultimately came to be labelled by mid-century, was by no means inevitable, nor does this period fit easily into a neat chronology of gradual 'improvement' in legal or social attitudes to wife-beating. ${ }^{45}$ After all, the repeated abuse suffered by the upper-middle-class writer Caroline Norton at the hands of her husband George, an aristocratic Tory Member of Parliament, was widely known and decried in society circles during the early nineteenth century. Given Caroline Norton's influential connections, her ongoing mistreatment had arguably been the trigger for bringing about the first reforms of child custody legislation in 1839 , and this remained significant in the run-up to the Matrimonial Causes Act 1857 that substantially expanded access to divorce in England and Wales. ${ }^{46}$ Even after the passage of this Act, the establishment of the Divorce Court in 1857, and an increasingly explicit dimension of class prejudice in press and political discussions of domestic violence, cases of wife-beating by middle- and upper-class British men were still represented in fiction, reported in the media, and came before the courts. ${ }^{47}$ Nonetheless, Victorian legislative reforms designed to address this subject, such as the Aggravated Assaults on Women and Children Act 1853, focused specifically on the vulnerability of those 'deserving' working-class women who were targeted by violent husbands, the heavy subtext being that married men from other class backgrounds did not commit such crimes. ${ }^{48}$ Cases of wife-killing in England were also profoundly affected by these issues, and guilty men could be treated with great sympathy if it was believed they had been provoked by their wife's unreasonable behaviour. When Richard Griffin was tried at the Old Bailey for the murder of his wife Ann in 1810, despite his open admission that he had slit his wife's throat, and 
multiple witnesses confirming that he had announced 'I shall be happy if she is a dead woman, and I shall die a happy man', he was found guilty of manslaughter rather than murder and sentenced to just a year's imprisonment at Newgate Prison and the fine of a single shilling. ${ }^{49}$ It is difficult to understand how the jury can have reached such a verdict, or the judge imposed such a lenient sentence, save that they believed Griffin's (unsubstantiated) claim that his wife was openly unfaithful, a claim that was also frequently presented as mitigation in the Indian criminal courts for the killing of wives. Ultimately, blurred lines in English courtrooms over what might count as 'legitimate correction', and the assumption that domestic violence was supposedly caused by the dual failures of working-class men to control themselves properly and of working-class women (either in choosing a husband poorly, or in 'provoking' violence) also played a key role in how British judges and civil servants paradoxically viewed this issue as simultaneously alien, familiar, and - above all inevitable when it came before the courts in colonial India.

For nineteenth-century British commentators, while the high rate of spousal abuse and in particular, lethal domestic violence - was agreed to be a significant problem in India, there was little enthusiasm for tackling it. Indeed, when the first substantial text on forensic medicine in India was published in 1870 , the author opened with the fictional example of a wife-murder as one of the most 'typical' suspicious deaths that a colonial physician would need to investigate. ${ }^{50}$ Wife-beating, and even the murder of wives, was generally believed to be an issue that remained impossible to solve, a regrettable but seemingly inescapable consequence of indigenous subjects belonging to an 'inferior' race and religion. ${ }^{51}$ Class, too, played an important if perhaps less overt role here in shaping these opinions. Although the occupation of prisoners was not systematically recorded in the Nizamat Adalat reports, the 
overwhelming majority of accused husbands where reference was made to their work seem to have been agricultural labourers. ${ }^{52}$ Middle-class Indian defendants in wife-murder cases were much more unusual, and perceived as exceptional. ${ }^{53}$ Indeed, when in 1853 the court reviewed the case of Gookoolnath Mitter, described as 'a man of education [who] is respectably connected, ${ }^{54}$ the Nizamat Adalat was actually moved to rebuke the presiding sessions judge for his explicit assumption that as a rare bhadralok defendant the man's claims of gross provocation and infidelity by his wife should be upheld without further investigation, and a purely nominal sentence of imprisonment bestowed. ${ }^{55}$ They did, nonetheless, eventually concur that the case should be reduced from one of murder to culpable homicide: Mitter was sentenced to five years' imprisonment with hard labour. ${ }^{56}$ Unlike the colonial consensus of the late nineteenth century that labelled Bengali men as effete when compared to their British counterparts, ${ }^{57}$ cases of wife murder brought before the Nizamat Adalat between 1805 and 1857 frequently emphasized instead the vulnerability of women to husbands who were often not only physically strong from a life of agricultural labour, but were represented as profoundly and dangerously emotionally volatile. ${ }^{58}$ This idea could also be tied to missionary discourses which inferred all African or South Asian peoples required the intervention of Christianity in order to form normal and healthy family relationships. ${ }^{59}$ As George Campbell, a civil servant working in Bengal described the situation in 1852:

The great majority of murders are of a domestic description, generally the result of passion or wounded pride; and in most cases there is a woman in the matter ... These cases then are not so much a question of police as of social habits; there is no preventing them. ${ }^{60}$

This laissez-faire attitude towards the (actual or imagined) prevalence of wife-killing by Indian men stands in stark contrast to the voluminous reports and regular investigative 
commissions during the nineteenth century generated by other violent crimes in India that were held by the imperial regime to result from indigenous beliefs and customs, such as sati, thuggee, or female infanticide. ${ }^{61}$ It is also a particularly startling absence given the repeated emphasis in many such official reports and popular narratives throughout the nineteenth century on Britain having a special obligation to stage dramatic social and legislative interventions in order to protect the lives of Indian women and girls. ${ }^{62}$ Although the age of victims that were teenaged or child brides might sometimes be mentioned by the court, this was not done systematically in the reports, nor did this factor guarantee harsher judicial treatment of the prisoner. ${ }^{63}$ In the case of domestic violence and wife murder, the normally ubiquitous colonial tendency to stake a claim for 'White men saving brown women from brown men ${ }^{64}$ was uncharacteristically absent. This did not prevent individual sessions judges and magistrates (or even those men sitting at the Nizamat Adalat itself) from lamenting the prevalence of wife-beating or wife-killing in India, expressing sympathy for victims, and urging that examples be made of offenders. Reference was occasionally made in the reports of the Nizamat Adalat to wife-beating or even wife killing being endemic across Bengal, and demanding that punishments for the guilty needed to be severe in order to deter other offenders. Yet such calls, however sincerely felt and meant, were always in regard to the court having tried specific cases - they do not ever seem to have resulted in sustained

campaigns for legislative change, or shifts in imperial policy relating to this subject. ${ }^{65}$

\section{THE HEART OF THE MATTER: PROVOCATION, JUSTIFICATION AND}

\section{ADULTERY}

The question of whether or not the dead woman had been unfaithful to her husband was a key element in a substantial proportion of the wife-murder cases reviewed by the Nizamat Adalat during this period. In no less than 48 cases of the 131 examined here (36.6 
per cent of the total), the convicted men attempted to justify the killing of their wife on these grounds. This was almost certainly because under Islamic law it was not a crime to kill either an unfaithful wife or her paramour if the husband did so after having actually witnessed them having sex, and, as I have noted, even the English courts would have treated such a killing as 'the lowest form of [manslaughter] because there could not be a greater provocation'. ${ }^{66}$ If the Nizamat Adalat could be convinced, this was, quite literally, a get out of jail free card for the prisoner. In all three of the cases between 1805 and 1857 where the Nizamat Adalat ordered the immediate release of a man convicted at a sessions court for the murder of his wife, this was because the court argued it had been successfully proven that the woman's death had followed immediately on him witnessing her commit adultery. ${ }^{67}$ What is perhaps surprising, however, in the light of the sustained willingness of the Nizamat Adalat to consider infidelity and other mitigating factors in wife killings as reducing the culpability of the husband, is how seldom actual releases occurred. No such wife-murder cases seem to have met the burden of evidence necessary to justify the husband's release from 1839 to 1857 . The Nizamat Adalat acknowledged the potential danger posed by accepting stories of wifely unfaithfulness too easily, and cases such as that of Government vs. Munoo in 1854, where the prisoner claimed (with no supporting evidence, and to the palpable incredulity of the court) to have stabbed his wife with a sword immediately after she had sex with three strangers while they were travelling on the road to his in-laws home, underscored this concern. ${ }^{68}$ In fact, one judge during the 1838 review of Muddun Patur's case questioned whether he could really be accepted as having killed his wife immediately on catching her and her lover together in the garden of his home, since she had been attacked and killed as she ran for the house after being discovered. Although the other two judges sitting in this case overruled their colleague's objection that this short span of minutes was enough time for Patur to have reasonably calmed himself and correspondingly move the verdict from justifiable to culpable 
homicide, it is worth noting that this was the last instance of a wife-murderer being ordered for immediate release by the Nizamat Adalat on the grounds he had committed no crime under Islamic law. ${ }^{69}$ Henceforth, the best a defendant could hope for was that the court would reduce the charge to culpable homicide on review in light of him having been 'provoked', and that the resulting prison sentence would be comparatively short. As I have shown above (Table 1.), this was in practice a somewhat likelier outcome than the possible alternative sentences of either life imprisonment, transportation, or a period of 7-14 years imprisonment.

In two further cases, although adultery of the wife was not formally raised as a plea of mitigation, the evidence heard by the court made oblique reference to this subject.

Neighbours testified in 1851 that they had attempted to intervene when a man named Googuria was heard accusing his wife of infidelity and threatening to murder her while he beat her, although he did not later repeat this claim when on trial. ${ }^{70}$ In another case, from 1853, the prisoner, Sheikh Kureem, claimed that he had killed his wife because she was going to leave him for another man, although there was no mention of an actual affair having taken place. ${ }^{71}$ In both these instances, however, the conduct of the guilty man meant that the court promptly dismissed any suggestion of this supposed infidelity or other circumstances as reducing the charge to one of culpable homicide. After his neighbours had stopped him beating his wife, and he had already branded her on the neck with a hot iron, Googuria had waited for the villagers to return to their homes, then tied his wife's hands and thrown her into the village well to drown. ${ }^{72}$ Despite the attempt of Sheikh Kureem to plead outraged masculine honour at the prospect of his wife leaving him, the court heard that the killing had taken place within a year of their ostensible reconciliation: he had originally thrown her out of the marital home with their newborn son after their marriage in 1842, and taken up for some years with another woman who he had also then deserted. ${ }^{73}$ Unsurprisingly, the 
Nizamat Adalat saw no reason in either case to mitigate the death sentence that had been passed by the sessions court upon these men, and confirmed that they should be executed.

\section{'REASSERTING AUTHORITY': THE ROLE AND RIGHTS OF HUSBANDS}

Just as Barbara Alpern Engel has observed was the case for Late Imperial Russia, in both India and England during the early nineteenth century 'Many abusive men suspected, or claimed to suspect, infidelity behind every act of wifely independence. ${ }^{74}$ Men who claimed that the death of their wife had resulted from either an attempt to avenge their own masculine dishonour or to reassert their role as head of the household had to do so with care. A husband who killed his wife might well be able to claim successfully, as did Binode Roy when his case was reviewed in January 1851; that he had beaten his wife before and had not intended for her to die on this occasion. ${ }^{75}$ The Nizamat Adalat was frequently willing to offer the benefit of the doubt to men who alleged their wife was unfaithful, and to consider this as grounds for reducing either the charge itself from murder to culpable homicide, or, even if the conviction for murder was upheld, issuing a sentence of imprisonment or transportation rather than execution. In a case from 1822, the prisoner claimed that his wife's adultery was so notorious that 'his neighbours had refused to associate with him on grounds of his wife's misconduct'. ${ }^{76}$ Although upholding his conviction for murder, the Nizamat Adalat decreed he should be sentenced to life imprisonment rather than death. ${ }^{77}$ This leniency did not extend, however, to cases in which witness testimony provided in the reports demonstrated that such suspicions on the part of the husband were baseless. When Hurree Singh claimed in 1805 that he had killed his wife after she repeatedly ran away from him into the forest to have affairs, his neighbours flatly insisted that there were no grounds for such beliefs and that the reason his wife kept running away had been a combination of childishness - she was only 12 years 
old - and that 'her mind was apparently deranged' ${ }^{78}$ The Court upheld the death penalty in Singh's case. ${ }^{79}$ Likewise, although Kufeeroodeen tried to claim his wife had been unfaithful when his case was reviewed in May 1851, both the sessions court and the Nizamat Adalat were scathing in their assessment of this defence. ${ }^{80}$ The good character of his wife, Mussamaut Bennoo, was widely attested to during his trial at the sessions court. ${ }^{81}$ In confirming the death sentence on the prisoner, one of the judges of the Nizamat Adalat who reviewed this case felt moved to remark that similar cases should be dealt with severely by the court, '...we know too well that there are men with hard and brutish temperaments, who will brook no opposition from those who are dependent upon them, ${ }^{82}$ Men whose neighbours or relatives testified that they had frequently had to intervene to prevent him abusing his wife in the past, or that the prisoner was known for his malice or ill-temper risked being made an example of by the court. Patan Gazee, whose case was reviewed in 1855, claimed that he had lived very happily with his teenaged wife. ${ }^{83}$ Yet it was established from the outset that during the eight years they had been married Gazee had become infamous in their community for having been 'habitually unkind to her, refusing even to allow her to pay occasional visits to her [mother] ${ }^{84}$ Tragically, it seemed that the reason for the killing was that Gazee had overheard the victim's mother saying to a friend she was going to consult a magistrate the following day in order to get her daughter away from the constant violence of her husband. Given that even the witness called for the defence 'in fact rather supported the case for the prosecution', it is perhaps unsurprising the Nizamat Adalat decreed he should suffer the death penalty. ${ }^{85}$ British judges reviewing these cases thus made a clear effort to take into account localised and customary attitudes to what a husband might or might not be 'allowed' to do. Murderous husbands condemned by their community as transgressing these boundaries were much more likely to suffer a severe punishment when their sentence was reviewed by the colonial authorities. 


\section{MOTIVELESS WIFE MURDERS AND INSANITY}

Relatively few of the men whose cases were reviewed by the Nizamat Adalat in this period were adjudged to be suffering from mental illness at the time that they killed their wives. Only four husbands were considered to fit within this category ( 3 per cent of the total). In some instances, this was fairly clear cut. Multiple witnesses testified in the case of Burkutoollah, reviewed in 1853, that he had suffered from mental health problems for over a year before he killed his wife. ${ }^{86}$ One villager noted that he was not normally violent, but 'Like other madmen he talked to himself' ${ }^{87}$ Because he had begun to behave so erratically, Burkutoollah's family had actually arranged for an exorcism the day before the murder in order to drive out the evil spirit they believed had sent him mad. ${ }^{88}$ Although the sessions judge himself was dubious, the civil surgeon gave it as his opinion that Burkutoollah had been insane at the time he killed his wife, and the Nizamat Adalat upheld this, acquitting him on the grounds of insanity and following the usual practice that like other insane prisoners he should be kept confined until such time as he recovered. ${ }^{89}$ Substantial evidence seems to have been needed for the courts to take this plea seriously and invariably this included the expert opinion of a medical man. ${ }^{90}$ Without this, an attempt at an insanity defence was unlikely to be believed. During the review of Rajkissore Dhanook's case in 1851, only the prisoner's mother-in-law had claimed he had suffered from mental illness previously, and it was not mentioned by other witnesses. ${ }^{91}$ The Nizamat Adalat dismissed the idea he had been insane as unsupported by the evidence, and confirmed the death sentence on Dhanook. ${ }^{92}$ Paralleling similar debates in the English courts during this period, some cases where a prisoner was not, ultimately, held to be insane also provoked considerable unease during the review about where precisely the boundary fell between mental illness, legal responsibility, and moral or intellectual weakness that did not preclude knowing right from wrong. ${ }^{93}$ For colonial lawyers 
and physicians, racist stereotyping of South and Southeast Asian men and women as prone to violent emotional outbursts arguably made drawing this boundary of criminal responsibility even more complicated than it was in Britain. ${ }^{94}$ The case of Bolaki, reviewed by the Nizamat Adalat in November 1850, was one in point. ${ }^{95}$ Neighbours testified during his trial at the Patna Sessions Court that they had heard cries coming from his house, where they found him bludgeoning his wife with a kodalee (a type of hoe). The couple were believed in their village to have a good relationship, and the sudden and lethal attack on his wife seemed to have been for no other reason the court could determine than because he was angry she had not finished preparing his meal. ${ }^{96}$ Although the sessions judge did not consider Bolaki to be mad, he noted that '....the prisoner was a man of violent temper, and susceptible of excitement to such an extent, that he might commit the utmost violence before he was well conscious of what he was doing' ${ }^{97}$

Complicating matters further, the civil surgeon testified that Bolaki was insane - but that in his opinion, this had been brought on by the shock of realising he had killed his wife, rather than prior to her murder. ${ }^{98}$ Concurring with this assessment, and agreeing with the sessions judge that the death penalty would nonetheless be unjust, the Nizamat Adalat ordered that he be sentenced to life imprisonment with hard labour at the Patna jail, with the guards under instructions to monitor him carefully for any further signs of mental illness. ${ }^{99}$

More common than a finding of insanity were those cases where the court found themselves searching in vain for a motive which could explain -however imperfectly - what had prompted a man to kill his wife. It is significant that despite the stated belief of some British officials that 'the practice of beating wives in this district for the most trivial offence is of frequent occurrence, and death often ensues in consequence', ${ }^{100}$ the courts usually worked on the assumption there must invariably have been some sort of provocation (even if 
the judges themselves considered this was grossly unfair to the dead woman) in most cases of alleged wife-murder that patient investigation by the authorities could uncover. Such assumptions rested on the idea that Indians of both sexes were prone to particular 'wildness' of character that was inflamed by adherence to tribal or caste customs. ${ }^{101}$ If such a motive could not be ascribed to the prisoner, the court then often struggled to assess what the most 'just' sentence might be for the case in question.

\section{CONCLUSIONS}

Attitudes to wife murders and domestic violence in early nineteenth century India were profoundly influenced by the permeable boundaries between 'acceptable' and 'unacceptable' conduct for married couples in England during this period. Although it was never the case that violent husbands in Bengal would automatically be viewed with sympathy by the Nizamat Adalat, the perception that Indian men (like working-class British men) were culturally and perhaps even psychologically incapable of self-control in the way middle-class British men were meant that the courts in both nations were often willing to take a lenient view of what constituted 'provocation' in these cases. Such sympathy, however, fell within very definite limits, and rested in part on either the degree to which a wife failed to conform to her expected role, or that the defendant could not be perceived as simply brutish. The suspicion of adultery by wives, in particular, remained a powerful plea to the judges if there was even limited evidence to support this claim. Such imported ideas were integral to the development of 'Anglo-Muhammadan' criminal law during the nineteenth century. It is also essential to recognise just how long these attitudes, and the case law that they helped to generate, persisted in both England and India. As late as 1946, the House of Lords formally upheld the principle during their review of Holmes v. D.P.P. that infidelity could still be considered 'reasonable provocation' for homicide if the defendant had actually witnessed the 
couple having sex immediately beforehand, although they added that in the future the rule must be applied that this principle now held just as true for women who killed unfaithful husbands or their mistresses as it had always been for men. ${ }^{102}$

\section{NOTES}

${ }^{1}$ William Macnaghten, Reports of Cases determined in the Court of Nizamut Adawlut, 3 vols. (Calcutta, 1827). See Vol. 2, Government against Chait Ram, pp.408-409.

${ }^{2}$ Dismissing Hindu traditions of criminal justice as 'absurd', East India Company officials only approved of civil matters that invoked it. In contrast, Islamic criminal law was considered an acceptable holdover from the Mughal regime, and so was applied to all Indian prisoners - even if the British in practice played fast and loose with its application. See Nancy Gardner Cassels, Social Legislation of the East India Company: Public Justice versus Public Instruction (New Delhi, 2010) p.20. 


\footnotetext{
${ }^{3}$ Macnaghten, Reports of Cases, p.409.

${ }^{4}$ Jörg Fisch, Cheap Lives and Dear Limbs: The British transformation of the Bengal criminal law, 1769-1817 (Wiesbaden, 1983); Michael Anderson, 'Islamic law and the colonial encounter in British India' in Ideologies and Institutions: A SOAS South Asia Reader ed. David Arnold and Peter Robb (Richmond, 1993) pp.165-185; Radhika Singha, A Despotism of Law: Crime \& Justice in Early Colonial India (Delhi, 1998); Scott Alan Kugle, 'Framed, Blame and Renamed: The Recasting of
} Islamic Jurisprudence in Colonial South Asia', Modern Asian Studies, 35 (2001) pp.257-313; Rudolph Peters, Crime and Punishment in Islamic Law: Theory and Practice from the Sixteenth to the Twentyfirst Century (Cambridge, 2005) pp.109-119.

${ }^{5}$ Sir William Blackstone, Blackstone's Commentaries on the laws and constitution of England: abridged for the use of students, and adapted to modern statutes and decisions (London, 1820) p.447; David Hume, Commentaries on the law of Scotland, respecting crimes, $3^{\text {rd }}$ ed. (Edinburgh, 1829) pp.215-216.

${ }^{6}$ Singha, A Despotism of Law, p.145.

${ }^{7}$ Jim Masselos, ‘Sexual Property/Sexual Violence: Wives in Nineteenth-Century Bombay’, South Asia Research, 12 (1992) pp.81-99.

${ }^{8}$ Padma Anagol, 'From the Symbolic to the Open: Women's Resistance in Colonial Maharashtra' in Behind the Veil: Resistance, Women and the Everyday in Colonial South Asia, ed. Anindita Ghosh (Basingstoke, 2008) pp.45-48.

${ }^{9}$ This was famously demonstrated by Catherine Hall, Civilising Subjects: Metropole and Colony in the English Imagination 1830-67 (Cambridge, 2002); but see also Zoë Laidlaw, Colonial Connections 1815-45: Patronage, the information revolution and colonial government (Manchester, 2005); Clare Anderson, Subaltern Lives: Biographies of Colonialism in the Indian Ocean World, 1790-1920 (Cambridge, 2012); Esme Cleall, Missionary Discourses of Difference: Negotiating Otherness in the British Empire, 1840-1900 (Basingstoke, 2012). 
${ }^{10}$ British officials in Egypt and Malaysia often looked to India when deciding how to interpret Islamic law in these jurisdictions. See Iza R. Hussin, The Politics of Islamic Law: Local Elites, Colonial Authority and the Making of the Muslim State (Chicago, 2016).

${ }^{11}$ Kirsten McKenzie, Scandal in the Colonies (Melbourne, 2004) p.7.

${ }^{12}$ Lauren Benton, Law and Colonial Cultures: Legal Regimes in World History 1400-1900 (Cambridge, 2002); Zoë Laidlaw, ‘Breaking Britannia's Bounds? Law, Settlers, and Space in Britain's Imperial Historiography', The Historical Journal, 55 (2012) pp.807-830.

${ }^{13}$ Sally Engle Merry, 'Legal Pluralism', Law \& Society Review, 22 (1988), pp. 869-896.

${ }^{14}$ Bonny Ibhawoh, Imperial Justice: Africans in Empire's Court (Oxford, 2013).

${ }^{15}$ David Lambert, White Creole Culture, Politics and Identity during the Age of Abolition (Cambridge, 2005); Richard Phillips, Sex, Politics and Empire: A Postcolonial Geography (Manchester, 2006); Deana Heath, Purifying Empire: Obscenity and the Politics of Moral Regulation in Britain, India and Australia (Cambridge, 2010).

${ }^{16}$ On this enduring idea see Laura Tabili, "We Ask for British Justice”: Workers and Racial Difference in Late Imperial Britain (Ithaca, NY, 1994).

${ }^{17}$ For example, developing 'personal law', whereby all civil law matters were governed by the religion of those involved. See Sir William Hay Macnaghten, Principles of Hindu and Mohammadan Law, Republished from the Principles and Precedents of the Same by the Late Sir William Hay Macnaghten, and edited by H.H. Wilson, $2^{\text {nd }}$ ed. (London, 1862).

${ }^{18}$ Bonny Ibhawoh, Imperialism and Human Rights: Colonial Discourses of Rights and Liberties in African History (Albany, 2007); Nandini Bhattacharyya-Panda, Appropriation and Invention of Tradition: The East India Company and Hindu Law in Early Colonial Bengal (New Delhi, 2008); James Jaffe, Ironies of Colonial Governance: Law, Custom and Justice in Colonial India (Cambridge, 2015).

${ }^{19}$ David A. Washbrook, 'Law, State and Agrarian Society in Colonial India', Modern Asian Studies, 15 (1981) pp. 649-721. 
${ }^{20}$ Clare Anderson, The Indian Uprising of 1857-8: Prisons, Prisoners and the Rebellion (London, 2007).

${ }^{21}$ In searching for these cases, I read through all the published reports of the Nizamat Adalat covering 1805 to 1857.

${ }^{22}$ A.F. Bellasis, Reports of Criminal Cases Determined in the Court of Sudder Foujdaree Adawlut, of Bombay (Bombay, 1849).

${ }^{23}$ Fisch, Cheap Lives, pp.108-116.

${ }^{24}$ Macnaghten, Reports, Vol. 1, pp.iii-v.

${ }^{25}$ Psychiatric facilities for Indian patients (criminal or otherwise) were extremely limited until 1858.

See Waltraud Ernst, 'Idioms of Madness and Colonial Boundaries: The Case of the European and "Native" Mentally Ill in Early Nineteenth-Century British India', Comparative Studies in Society and History, 39 (1997) pp.153-181.

${ }^{26}$ C.R. Baynes, Hints on Medical Jurisprudence, Adapted and Intended for the Use of Those Engaged in Judicial and Magisterial Duties (Madras, 1854) p.iii. Baynes emphasized that this was intended to adapt existing works, especially Alfred Swaine Taylor, A Manual of Medical Jurisprudence (London, 1844), for the colonial practitioner.

${ }^{27}$ Government vs. Khateer Sheikh and Baher Sheikh, Reports of Cases Determined in the Court of Nizamut Adawlut; For 1855, With an Index. Part II (Calcutta, 1856) pp.61-63; Theodric Romeyn Beck, Elements of Medical Jurisprudence, $7^{\text {th }}$ ed. (London, 1842).

${ }^{28}$ Peters, Crime and Punishment, p.119.

${ }^{29}$ Fisch, Cheap Lives, pp.49-56; 100-104.

${ }^{30}$ John W. Kaye, The Administration of the East India Company; A History of Indian Progress, $2^{\text {nd }}$ ed. London, 1853) p.324.

${ }^{31}$ Daniel Duman, The Judicial Bench in England, 1727-1875: The Reshaping of a Professional Elite (London, 1982). 
${ }^{32}$ Elizabeth Kolsky, 'The Rule of Colonial Indifference: Rape on Trial in Early Colonial India, 180557', Journal of Asian Studies, 69 (2010), p.1093.

${ }^{33}$ Clare Anderson, Convicts in the Indian Ocean: Transportation from South Asia to Mauritius, 1815 53 (Basingstoke, 2000).

${ }^{34}$ Sukhee Guraun against Ramchurn Garaun, Macnaghten, , Reports of Cases, Vol. 2, pp.350-351; Government against Nujeeb Khan, Macnaghten, , Reports of Cases, Vol. 3, pp.327-329; Government against Tummesoodeen, son of Zamaloodeen, Reports of Cases Determined in the Court of Nizamut Adawlut; Vol. IV. (Calcutta, 1841) pp.248-250; Easin Moollah vs. Hybutoollah Khoondkar, Reports of Cases Determined in the Court of Nizamut Adawlut; From January to June 1851, With an Index (Calcutta, 1852) pp.66-68; Government vs. Mosabdi Sheikh, Reports of Cases Determined in the Court of Nizamut Adawlut; From July to December 1854, With an Index (Calcutta, 1855) pp.263-265. ${ }^{35}$ Government and Aseer Mahomed Chowkeedar vs. Lobanee Doss alias Nobin Doss and Musst. Tara alias Tarun, Reports of Cases Determined in the Court of Nizamut Adawlut; From January to June 1855, With an Index (Calcutta, 1856) pp.500-503.

${ }^{36}$ For example, the murder by Kadeer Karigur of his pregnant wife and three children, reviewed by the Nizamat Adalat in 1854 but not included in Table 1 above, was unanimously condemned by all the officials involved as 'most atrocious', and deserving of the death penalty. See Reports of Cases Determined in the Court of Nizamut Adawlut; From January to June 1854, With an Index (Calcutta, 1854) pp.100-102.

${ }^{37}$ Bombay Times and Journal of Commerce, 8 July 1846, p.452; Bombay Times and Journal of Commerce, 22 July 1846, p.492; Bombay Times and Journal of Commerce, 25 July 1846, pp.499-500 and p.503.

${ }^{38}$ Durba Ghosh, 'Household Crimes and Domestic Order: Keeping the Peace in Colonial Calcutta, c.1770- c.1840', Modern Asian Studies, 38 (2004) pp.598-624; Jordanna Bailkin, 'The Boot and the Spleen: When Was Murder Possible in British India?', Comparative Studies in Society and History, 48 (2006) pp.463 - 494; Elizabeth Kolsky, Colonial Justice in British India (Cambridge, 2010). 
${ }^{39}$ Martin J. Wiener, Men of Blood: Violence, Manliness, and Criminal Justice in Victorian England (Cambridge, 2004); Elizabeth A. Foyster, Marital Violence: An English Family History, 1660-1857 (Cambridge, 2005); Joanne Bailey, “"I dye [sic] by Inches": locating wife beating in the concept of a privatisation of marriage and violence in eighteenth-century England', Social History 31 (2006) pp.273-294.

${ }^{40}$ Sir William Blackstone, Commentaries on the Law of England: In Four Books, With An Analysis of the Work, $19^{\text {th }}$ ed., 4 vols. (London, 1836). See Vol. 4, p.444.

${ }^{41} R$. v. Jackson (1891) All ER Rep 61, 1 QB 67 I.

${ }^{42}$ Blackstone, Commentaries on the Law of England, Vol. 4, p.445.

${ }^{43}$ Evans v. Evans (1790) 161 ER 466, 1 Hag Con 35, [1790] EW Misc J45.

44 'First Report of the Royal Commission on Divorce', Parliamentary Papers, 1852-3, Cd. 1604, Vol. XL, pp.249-330 (p.265).

${ }^{45}$ Joanne Bailey \& Loreen Giese, 'Marital cruelty: reconsidering lay attitudes in England, c. 1580 to 1850', History of the Family 18 (2013) pp.289-305.

${ }^{46}$ Caroline Norton, English Laws for Women in the Nineteenth Century (London, 1854).

${ }^{47}$ A. James Hammerton, Cruelty and Companionship: Conflict in Nineteenth-Century Married Life (London, 1992); Lisa Surridge, Bleak Houses: Marital Violence in Victorian Fiction (Athens, OH, 2005).

${ }^{48}$ Shani D'Cruze, Crimes of outrage: Sex, violence and Victorian working women (London, 1998); Ben Griffin, The Politics of Gender in Victorian Britain: Masculinity, Political Culture and the Struggle for Women's Rights (Cambridge, 2012) pp.68-73.

${ }^{49}$ Old Bailey Proceedings Online (www.oldbaileyonline.org, version 7.2, 16 February 2016), September 1810, trial of RICHARD GRIFEIN (t18100919-56).

${ }^{50}$ Norman Chevers, A Manual of Medical Jurisprudence for India (Calcutta, 1870) p.2.

${ }^{51}$ Kolsky, ‘The Rule of Colonial Indifference', p.1094. 
${ }^{52}$ For key context see Sugata Bose, Peasant Labour and Colonial Capital: Rural Bengal Since 1770 (Cambridge, 1993).

${ }^{53}$ Ray Utsa, 'Consumption and the Making of the Middle-Class in South Asia', History Compass, 12 (2014) pp.11-19.

${ }^{54}$ Government vs. Gookoolnath Mitter, Reports of Cases Determined in the Court of Nizamut Adawlut; From January to June 1853, With an Index (Calcutta, 1854) pp.702-711 (p.702).

${ }^{55}$ Ibid., pp.706-708.

${ }^{56}$ Ibid., p.711.

${ }^{57}$ Mrinalini Sinha, Colonial Masculinity: The 'Manly Englishman' and the 'Effeminate Bengali' in the Late Nineteenth Century (Manchester, 1995).

${ }^{58}$ This view persisted for some time. See also Chevers, A Manual, p.2.

${ }^{59}$ Cleall, Missionary Discourses.

${ }^{60}$ George Campbell, Modern India: A Sketch of the System of Civil Government (London, 1852), p.499.

${ }^{61}$ Daniel J.R. Grey, 'Creating the "Problem Hindu": Sati, Thuggee and Female Infanticide in India, 1800-60,' Gender \& History, 25 (2013) pp.498-510.

${ }^{62}$ See for example 'Papers relating to East India affairs: viz. Hindoo widows, and voluntary immolations', PP, 1821, No. 749, Vol. XVIII, pp.295-565; ‘East India Affairs. Copy of all Correspondence which has taken place on the subject of Hindoo Infanticide, and of all Proceedings of the Indian Government, with regard to that Practice; 1789-1820', PP, 1824, No. 426, Vol. XXIII, pp.167-311.

${ }^{63}$ In 25 cases, (19 per cent of the total), the age of the victim was listed in the report as between 8 and 17 years, but in most cases the age of the murdered woman was not given. No cases specifically invoked the victim's age as a possible factor for consideration when determining guilt or punishment. ${ }^{64}$ Gayatri Chakravorty Spivak, 'Can the Subaltern Speak?' in Marxism and the Interpretation of Culture ed. Cary Nelson and Larry Grossberg (Urbana, IL, 1988) p.297. 
${ }^{65}$ In six wife-murder cases - all bar one of which, heard in 1822 , were reviewed by the court during the early 1850 s - judges made specific reference to the disturbing frequency of domestic violence in the area.

${ }^{66}$ Blackstone, Commentaries, Vol. 4, p.191.

${ }^{67}$ These were Government against Thundee, Macnaghten, Reports of Cases, Vol. 1, p.130;

Government against Chait Ram, Macnaghten, , Reports of Cases, Vol. 2, pp.408-409; Government against Manick Muhto, Reports of Cases Determined in the Court of Nizamut Adawlut; Vol. IV. (Calcutta, 1841) pp.168-169; and Government vs. Muddun Patur, Reports of Cases Determined in the Court of Nizamut Adawlut; With an Index to the First Five Volumes (Calcutta, 1841) pp.89-92.

${ }^{68}$ Government vs. Munoo, Reports of Cases Determined in the Court of Nizamut Adawlut; From July to December 1854, With an Index (Calcutta, 1855) pp.112-114.

${ }^{69}$ Government vs. Muddun Patur, Reports of Cases, pp.89-92.

${ }^{70}$ Government vs. Googuria alias Goonduria and Bhinka Chowkeedar, Reports of Cases Determined in the Court of Nizamut Adawlut; From July to December 1851, With an Index (Calcutta, 1852) pp.1512-1519.

${ }^{71}$ Government and Musst. Dookhinee vs. Sheikh Kurreem, Reports of Cases Determined in the Court of Nizamut Adawlut; From July to December 1853, With an Index (Calcutta, 1855) pp.881-883.

${ }^{72}$ Government vs. Googuria alias Goonduria and Bhinka Chowkeedar, Reports, pp. 1512-1519.

${ }^{73}$ Government and Musst. Dookhinee vs. Sheikh Kurreem, Reports, p.881.

${ }^{74}$ Barbara Alpern Engel, Breaking the Ties That Bound: The Politics of Marital Strife in Late Imperial Russia (Ithaca, 2011) p.115.

${ }^{75}$ The Nizamat Adalat agreed on these grounds to sentence Roy to transportation rather than death.

See Oojullah Chassani vs. Binode Roy, Reports of Cases Determined in the Court of Nizamut Adawlut; From January to June 1851, With an Index (Calcutta, 1852) pp.35-45.

${ }^{76}$ Government against Nunda, in Macnaghten, Reports of Cases, Vol. 2, p.167.

${ }^{77}$ Ibid, p.168. 
${ }^{78}$ Vakeel of Government against Hurree Singh. See Macnaghten, Reports of Cases, Vol. 1, p.32.

${ }^{79}$ Ibid, p.33.

${ }^{80}$ Government vs. Kufeeroodeen, Reports of Cases Determined in the Court of Nizamut Adawlut;

From January to June 1851, With an Index (Calcutta, 1851) pp.510-513.

${ }^{81}$ Ibid, p.510.

${ }^{82}$ Ibid, p.513.

${ }^{83}$ Government and Sreemuttee Joynub vs. Patan Gazee alias Patoo, Reports of Cases Determined in the Court of Nizamut Adawlut; For 1855, With an Index. Part II (Calcutta, 1856), pp.989-992.

${ }^{84}$ Ibid, p.989.

${ }^{85}$ Ibid, p.991.

${ }^{86}$ Government vs. Burkutoollah, Reports of Cases Determined in the Court of Nizamut Adawlut;

From January to June 1853, With an Index (Calcutta, 1854) pp.76-81.

${ }^{87}$ Ibid, p.77.

${ }^{88}$ Ibid, p.77.

${ }^{89}$ Ibid, p.81.

${ }^{90}$ A valuable comparative perspective on British and imperial medico-legal attitudes to criminal insanity is provided by Catherine L. Evans, 'Persons Dwelling in the Borderland: Responsibility and Criminal Law in the Late Nineteenth Century British Empire' (Unpublished PhD thesis, Princeton University, 2016).

${ }^{91}$ Government vs. Rajkissore Dhanook, Reports of Cases Determined in the Court of Nizamut Adawlut; From January to June 1851, With an Index (Calcutta, 1852) pp.144-153.

${ }^{92}$ Government vs. Rajkissore Dhanook, Reports of Cases, pp.151-153.

${ }^{93}$ Joel Peter Eigen, Unconscious Crime: Mental Absence and Criminal Responsibility in Victorian London (Baltimore, MD, 2003).

${ }^{94}$ Jonathan Saha, 'Madness and the Making of a Colonial Order in Burma', Modern Asian Studies, 47 (2013) pp. 406-435. 
${ }^{95}$ Government vs. Bolaki, Reports of Cases Determined in the Court of Nizamut Adawlut; With an Index to the Sixth Volume, 1841-1850 (Calcutta, 1852) pp.333-337.

${ }^{96}$ Ibid, p.333.

${ }^{97}$ Ibid, pp.336-337.

${ }^{98}$ Ibid,p.335.

${ }^{99}$ Ibid, p.337.

${ }^{100}$ Government vs. Mojomdee, Reports of Cases Determined in the Court of Nizamut Adawlut; From July to December 1854, With an Index (Calcutta, 1855) p.690.

${ }^{101}$ Ajay Skaria, 'Shades of Wildness: Tribe, Caste and Gender in Western India', Journal of Asian Studies, 56 (1997) pp.726-745.

${ }^{102}$ See Holmes v. D.P.P. [1946] A.C. 588, at p.598. On the broader context of infidelity in postwar Britain see Claire Langhamer, 'Adultery in postwar England', History Workshop Journal, 62 (2006) pp.86-115; Tanya Evans, 'The Other Woman and her Child: extra-marital affairs and illegitimacy in twentieth-century Britain', Women's History Review, 20 (2011) pp.47-65. 